\title{
Allergic Rhinitis and Its Impact on Asthma in Asia Pacific and the ARIA Update 2008
}

\author{
Ruby Pawankar, ${ }^{1}$ Chaweewan Bunnag, ${ }^{2}$ Nikolai Khaltaev, ${ }^{3}$ and Jean Bousquet ${ }^{3}$
}

\begin{abstract}
The prevalence of allergic diseases such as allergic rhinitis (AR) and asthma are markedly increasing to epidemic proportions worldwide as societies adopt Western lifestyles. An estimated 300 million persons worldwide have asthma, about $50 \%$ of whom live in developing countries, and about 400 million people suffer from AR. AR has a marked impact on quality of life, socially, at school, and in the workplace and is a huge socioeconomic burden. Thus, there was clearly a need for a global evidence-based guideline not only for managing $\mathrm{AR}$ but also highlighting the interactions between the upper and lower airways including diagnosis, epidemiology, common risk factors, management, and prevention. The Allergic Rhinitis and its Impact on Asthma (ARIA) document was first published in 2001 as a state-of-the-art document for the specialist, the general practitioner, and other health care professionals. Subsequent research and increasing knowledge have resulted in the ARIA 2008 update. The present review summarizes the ARIA update with particular emphasis on the current status of AR and asthma in Asia Pacific.
\end{abstract}

Key Words: allergic rhinitis, asthma, ARIA update, evidence-based, Asia Pacific

(WAO Journal 2012; 5:S212-S217)

A llergic rhinitis (AR) is an IgE-mediated inflammation of the nasal mucosa induced after allergen exposure and presents with the 3 cardinal symptoms of sneezing, nasal obstruction, and rhinorrhea. AR is a global health problem that causes major illness and disability worldwide. It affects social life, sleep, school, and work. ${ }^{1-5}$ The economic impact of AR is substantial.

More than 400 million patients suffer from $\mathrm{AR}^{6-9}$ but there are still differences between rural and urban areas, both in developed and developing countries, ${ }^{8,10-12}$ possibly because of differences in immune reactions. ${ }^{13}$ A large number of patients also suffer from nonallergic rhinitis ${ }^{14}$ but the characterization of this disease is unclear as there are many phenotypes of nonallergic rhinitis.

In 2001, the ARIA (Allergic Rhinitis and its Impact on Asthma) World Health Organization (WHO) evidence-based document was published ${ }^{15}$ and the statements of evidence for

From the ${ }^{1}$ Nippon Medical School, Tokyo, Japan; ${ }^{2}$ Siriraj Hospital Mahidol University, Bangkok, Thailand; Geneva, Switzerland; and ${ }^{3}$ University, Hospital and INSERM, Montpellier, France.

Correspondence to: Dr. Ruby Pawankar, PhD, MD, Nippon Medical School, Tokyo, Japan. E-mail: pawankar.ruby@gmail.com

Copyright $($ C 2012 by World Allergy Organization the development of ARIA followed WHO rules and were based on those of Shekelle et al. ${ }^{16}$

The ARIA document was intended to be a state-of-theart review for the specialist and for the general practitioner and other health care professionals to update their knowledge of AR, to highlight the impact of AR on asthma, to provide an evidence-based documented revision on the diagnosis methods and the treatments available, and to propose a step wise approach to the management of the disease.

\section{ARIA UPDATE 2008}

As a result of a large number of papers with new information on existing drugs, mechanisms, and newer therapies published during the past 7 years, ${ }^{17-22}$ it was important to have an ARIA update.

- The ARIA classification proposed "intermittent and persistent" have been validated, ${ }^{23-26}$ although some authors proposed extension of the severity of AR to 3 levels. ${ }^{27,28}$ However, because this would not lead to treatment differences, the ARIA experts proposed continuation of the classification of rhinitis severity as "mild" or "moderate/severe."

- New methods of diagnosis have been proposed for allergic and nonallergic rhinitis. ${ }^{29-32}$ The diagnosis of AR is often easy, but in some cases it may cause problems and many patients are still underdiagnosed, often because they do not perceive the symptoms of rhinitis as a disease.

- Furthermore, the gaps in our knowledge in the first ARIA document, which include some aspects of treatment with complementary and alternative medicine, ${ }^{18}$ sports and rhinitis in athletes, ${ }^{19,33,34}$ and rhinitis and its links with asthma in children, ${ }^{35-41}$ have been addressed in the ARIA update.

A large list of treatments was considered in the ARIA 2008 update. $^{42-44}$ With respect to pharmacologic treatments, intranasal corticosteroids have been recommended to be the first-line therapy in patients with moderate to severe disease and are also effective on ocular symptoms, ${ }^{45} \mathrm{H}_{1}$ antihistamines are important treatments for all patients, and leukotriene receptor antagonists are particularly important for patients with rhinitis and asthma. ${ }^{46,47}$ However, tertiary prevention of allergy is still a matter of debate because clinical trials do not usually show any efficacy of single allergen avoidance measures. ${ }^{17}$ Sublingual allergen-specific immunotherapy has proven to be 
a safe and effective treatment, ${ }^{48-51}$ but clinical trials need to be standardized. ${ }^{52,53}$ An algorithm of the management of AR is provided (Fig. 1). However, there is continuous progress in our understanding of the mechanisms of $\mathrm{AR}$, and novel treatment approaches are constantly published. ${ }^{54}$ Nonallergic rhinitis is still a matter of discussion and effective treatment may be difficult. $^{55}$

Another important aspect of the ARIA update was to consider the comorbidities of AR, and in particular asthma. Epidemiologic studies have consistently shown that asthma and rhinitis often coexist in the same patients in every region of the world. ${ }^{56-59}$ Most patients with asthma have rhinitis, but the prevalence of asthma in patients with rhinitis still needs to be assessed. ${ }^{60,61}$ Adults and children with asthma and documented concomitant AR experience more asthmarelated hospitalizations and physician visits, and incur higher asthma drug costs, than adults with asthma alone. ${ }^{62-65}$ These patients also experience more frequent absences from work and decreased productivity. However, some studies have not shown such an association. ${ }^{66}$

Many patients with AR have an increased bronchial reactivity to methacholine or histamine, ${ }_{67}^{67}$ especially during and some time after the pollen season. ${ }^{68,69}$ Nasal and bronchial inflammation are often related, ${ }^{70}$ but remodeling of the nose and bronchi seem to differ. ${ }^{71}$

Intranasal treatment of the nose does not considerably impact the lower airways, ${ }^{72}$ possibly because the characterization of seasonal asthma needs more insight ${ }^{73}$ and most studies have been carried out on this disease. However, some compelling data suggest that new studies with innovative methods need to be initiated. ${ }^{47,74,75}$ Oral drugs acting on asthma and rhinitis have an effect on both sites. ${ }^{46}$ Research has also shown that the addition of nasal topical corticosteroids to standard asthma treatment reduces severe exacerbations of asthma by

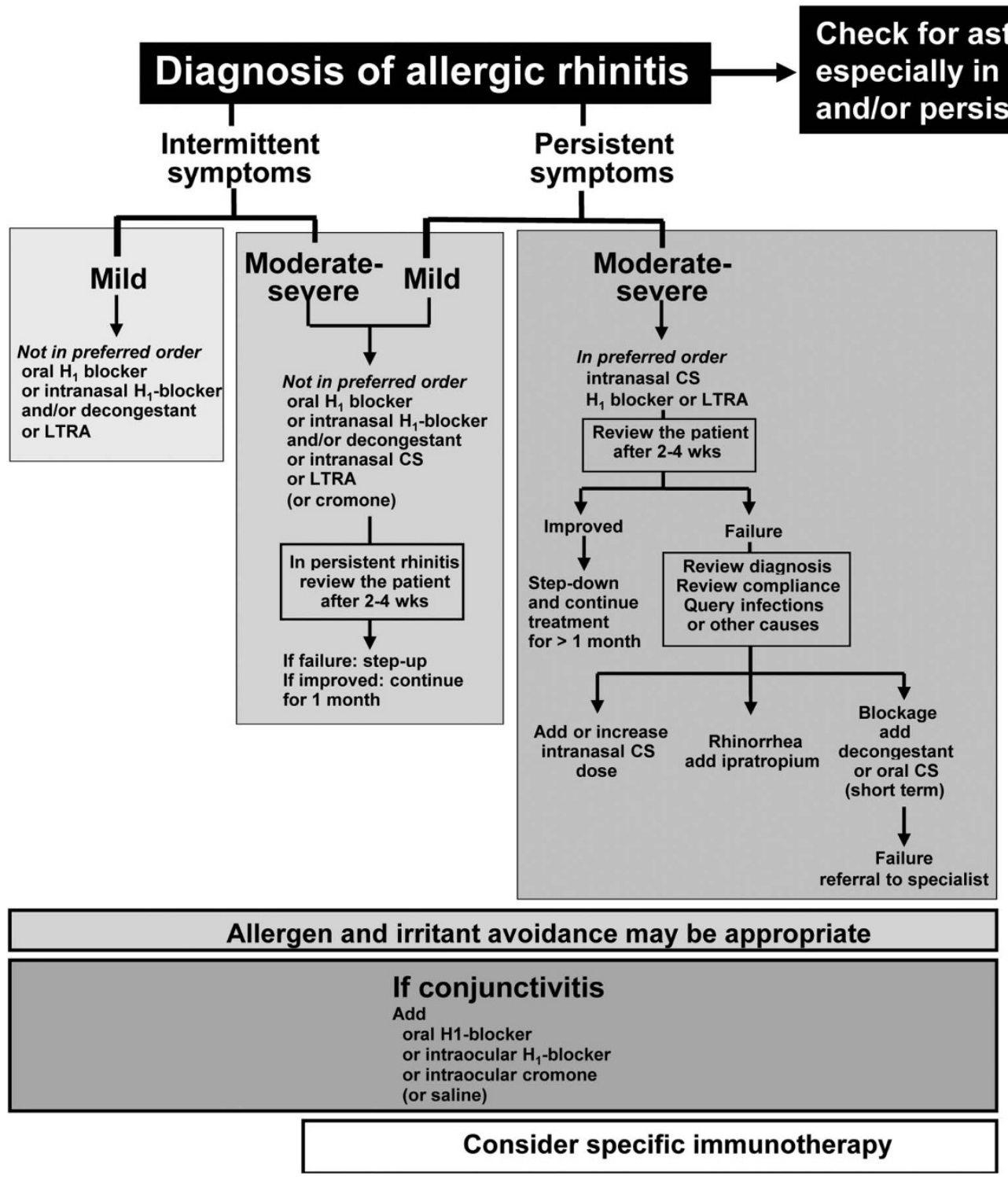

FIGURE 1. An algorithm of the management of Allergic Rhinitis ARIA update 2008. 
almost $50 \%{ }^{79}$ Allergen-specific immuno-therapy in patients with AR has a prolonged preventive effect on the development of asthma when stopped. ${ }^{76}$

\section{ASTHMA AND ALLERGIC RHINITIS IN ASIA PACIFIC}

The prevalence of allergic diseases in Asia varied widely but was found to be rising (asthma 29.1\%; AR up to $45 \%$ ) mostly in low- and middle-income countries. ${ }^{80,81}$ In Thailand, the prevalence of all 3 major allergic diseases increased significantly from the ISAAC phase I survey performed in 1995; that is, asthma increased from $12.2 \%$ to $14.5 \%$, AR from $37.9 \%$ to $50.6 \%$, and eczema from $9.8 \%$ to $15.7 \%$. In Japan, rhinitis has increased from $3.8 \%$ in 1982 to $32 \%$ and asthma from $4.6 \%$ in $1992^{82}$ to $9.1 \%$ (Akasawa A, 2006, unpublished) and more than $42 \%$ of patients with asthma have AR. The prevalence of childhood asthma in Taiwan has increased from $1.3 \%$ in 1974 to $5.07 \%$ in $1985,{ }^{83}$ and more recently, the overall cumulative and 12-month prevalence of wheezing and rhinitis in younger children 10 to 12 years was $8.2 \%$ and $44.4 \%$, respectively; and in the older children 13 to 15 years, $6.9 \%$ and $42.2 \%{ }^{84}$ Similarly, in Singaporean preschoolers, the cumulative and previous 12-months prevalence of wheezing was $27.5 \%$ and $16.0 \%$, respectively, and the current asthma and rhinitis prevalence was $11.7 \%$ and $25.3 \%$, respectively. By contrast, the prevalence of current wheezing, diagnosed asthma, and allergic rhinoconjunctivitis in Tibet was $0.8 \%, 1.1 \%$, and $5.2 \%$, respectively. ${ }^{85}$ Although asthma prevalence in rural Bangladesh is $16.1 \%{ }^{86}$ and in Pakistan there is a doubling of the prevalence of AR and asthma in ISAAC III as compared with ISAAC I, in a study in urban India the overall prevalence of asthma was $2.38 \% .{ }^{87}$ Prevalence of allergic rhinitis in 5- to 11-year-old children in Vietnam is $34.9 \%{ }^{88}$ and prevalence of allergic rhinitis in patients with asthma is $48.54 \%$ (Le Van Khang et al. Study of sensitivity, specificity of house dust mite allergen made in Vietnam in diagnosis of asthma. Ministry of Health of Vietnam, January 2002 to December 2004, www.cimsi.org.vn). Asthma prevalence in Australia increased from 8\% in 1989-1990 to 11\% in 1995 but the prevalence plateaued in recent years with a 2004 prevalence of asthma at $14 \%$ to $16 \%$ of children and $10 \%$ to $12 \%$ of adults. ${ }^{89}$

Although overall regional data for adults is scant, it is estimated that $1 \%$ to $10 \%$ have asthma and $10 \%$ to $32 \%$ have AR. In a more recent study, the self-reported prevalence of $\mathrm{AR}$ in China had wide variations, ranging from $<10 \%$ to $>20 \%$, with about $15 \%$ suffering from persistent AR. ${ }^{90}$ More recent data showed an increase in prevalence of AR in Korea from $6 \%$ to $10 \%{ }^{90}$ to $>20 \%{ }^{91}$ in the adult population. The distribution of the severity of AR was mild intermittent $(25.7 \%)$, moderate to severe intermittent (16.4\%), mild persistent $(16.4 \%)$, and moderate to severe persistent $(41.2 \%){ }^{92}$

\section{Comorbid Allergic Rhinitis and Asthma}

Recent data showed a very high comorbid rate of asthma and rhinitis as $60 \%$ to $80 \%$ of patients with asthma had rhinitis symptoms. ${ }^{93}$ The younger patients with asthma had a higher comorbid rate of rhinitis $(80 \%)$ than elderly patients (60\%); furthermore, patients with asthma who also had rhinitis presented more severe clinical symptoms in both adults and children, indicating that rhinitis may affect asthma severity and outcome. ${ }^{93}$

Although aeroallergens that trigger allergy and asthma in Asia Pacific vary from area to area, house dust mites are the major triggering allergen in most of Asia followed by pollens, insects, molds, and fungi. ${ }^{94}$

\section{Impact on Quality of Life}

In a study on patient perceptions of asthma management across Asia, patients reported frequent and unnecessary symptoms and exacerbations because of a lack of adequate asthma control. ${ }^{95}$ Twenty-seven percent of adults and $37 \%$ of children with asthma reported absences from work or school in the previous year because of asthma, and $40 \%$ required hospitalization, emergency department visits, or unscheduled emergency visits to other health care facilities in the previous year. ${ }^{95}$ Asthma severity varied, with Vietnam and China reporting the most patients with severe, persistent symptoms. Absenteeism from work was highest in the Philippines (46.6\%) and lowest in South Korea (7.5\%). In a survey of parents of children with asthma in 4 Asian countries, most children with asthma (73\%) had pre-existing symptoms of AR and asthma with comorbid AR substantially affecting their quality of life and worsening their asthma symptoms. ${ }^{5}$ However, awareness of the comorbidity of AR and asthma among the parents of children with asthma was only about $50 \%$.

From the evidence listed in this summary, it is clear that there is a high linkage between asthma and AR in the Asia Pacific too. It is therefore recommended that patients with persistent AR should be evaluated for asthma, including appropriate history taking and spirometric parameters, at an early stage. However, patients with asthma should be evaluated for rhinitis. Unfortunately, in reality there is a gap in this practice in many countries in the region. Partly, this is due to the lack of allergy medicine as a recognized speciality in some countries and to governmental regulations restricting specialists to practice as organ-based specialists. To resolve this problem and to have an integrated therapeutic strategy is one of the major challenges in the Asia-Pacific region.

On the basis of these constraints, we also need to consider treatment strategies that can really treat both the upper and the lower airway diseases. Leukotriene receptor antagonists are recommended for patients with both rhinitis and asthma in this ARIA summary. As the only established etiological treatment for allergic diseases, allergen-specific immunotherapy (SIT) needs to be highlighted as well.

\section{CONCLUSIONS}

The prevalence of asthma and AR is increasing in Asia Pacific and the prevalence of comorbidity is high. ${ }^{96}$ The perception of patients and physicians regarding the links between asthma and rhinitis varies between countries, but seems to be higher than expected. ${ }^{77,78}$ However, knowledge is not directly translated into practice because fewer physicians coprescribe treatments for rhinitis and asthma in the same patient. 
The recommendations of the ARIA workshop in 1999 are still valid, ${ }^{15}$ and in particular, it is recommended that all patients with AR, particularly if it is persistent, should be evaluated for asthma. AR is not only a risk factor for underlying asthma but could be a risk factor for asthma exacerbations. Patients with asthma should likewise be evaluated for rhinitis, and a combined strategy should ideally be used to treat the upper and lower airway diseases in terms of efficacy and safety.

\section{ACKNOWLEDGMENT}

This article is based on the presentation given at the BANYU Symposium at the 20th World Allergy Congress in Bangkok in December 2007.

\section{REFERENCES}

1. Canonica GW, Bousquet J, Mullol J, Scadding GK, Virchow JC. A survey of the burden of allergic rhinitis in Europe. Allergy. 2007;62 (Suppl. 85):17-25.

2. van Oene CM, van Reij EJ, Sprangers MA, Fokkens WJ. Quality-assessment of disease-specific quality of life questionnaires for rhinitis and rhinosinusitis: A systematic review. Allergy. 2007;62(12):1359-1371.

3. Schatz M. A survey of the burden of allergic rhinitis in the USA. Allergy. 2007;62(Suppl. 85):9-16.

4. Walker S, Khan-Wasti S, Fletcher M, Cullinan P, Harris J, Sheikh A. Seasonal allergic rhinitis is associated with a detrimental effect on examination performance in United Kingdom teenagers: Case-control study. J Allergy Clin Immunol. 2007;120(2):381-387.

5. Valovirta E, Pawankar R. Survey on the impact of comorbid allergic rhinitis in patients with asthma. BMC Pulm Med. 2006;6(Suppl 1): S3:1-10.

6. Bousquet J, Dahl R, Khaltaev N. Global alliance against chronic respiratory diseases. Allergy. 2007;62(3):216-223.

7. Bousquet J, Khaltaev N. Global surveillance, prevention and control of chronic respiratory diseases: a comprehensive approach. Geneva, Switzerland: Global Alliance against Chronic Respiratory Diseases, World Health Organization; 2007. ISBN 978924156346 8. 148 pages.

8. Asher MI, Montefort S, Björkstén B, Lai CK, Strachan DP, Weiland SK, Williams H. Worldwide time trends in the prevalence of symptoms of asthma, allergic rhinoconjunctivitis, and eczema in childhood: ISAAC Phases One and Three repeat multicountry cross-sectional surveys. Lancet. 2006;368(9537):733-743.

9. Ait-Khaled N, Odhiambo J, Pearce N, Adjoh KS, Maesano IA, et al. Prevalence of symptoms of asthma, rhinitis and eczema in 13- to 14-yearold children in Africa: The International Study of Asthma and Allergies in Childhood Phase III. Allergy. 2007;62(3):247-258.

10. Pekkarinen PT, von Hertzen L, Laatikainen T, Mäkelä MJ, Jousilahti P, et al. A disparity in the association of asthma, rhinitis, and eczema with allergen-specific IgE between Finnish and Russian Karelia. Allergy. 2007;62(3):281-287.

11. Majkowska-Wojciechowska B, Pelka J, Korzon L, Kozlowska A, Kaczala M, et al. Prevalence of allergy, patterns of allergic sensitization and allergy risk factors in rural and urban children. Allergy. 2007;62 (9):1044-1050

12. Viinanen A, Munhbayarlah S, Zevgee T, Narantsetseg L, Naidansuren T, et al. The protective effect of rural living against atopy in Mongolia. Allergy. 2007;62(3):272-280.

13. van Ree R, Yazdanbakhsh $M$. Allergic disorders in African countries: Linking immunology to accurate phenotype. Allergy. 2007;62(3):237-246.

14. Molgaard E, Thomsen SF, Lund T, Pedersen L, Nolte H, Backer V. Differences between allergic and nonallergic rhinitis in a large sample of adolescents and adults. Allergy. 2007;62(9):1033-1037.

15. Bousquet J, Van Cauwenberge P, Khaltaev N. Aria Workshop Group; World Health Organization. Allergic rhinitis and its impact on asthma. $J$ Allergy Clin Immunol. 2001;108(5 Suppl):S147-S334.

16. Shekelle PG, Woolf $\mathrm{SH}$, Eccles M, Grimshaw J. Clinical guidelines: Developing guidelines. BMJ. 1999;318(7183):593-596.
17. Custovic A, Wijk RG. The effectiveness of measures to change the indoor environment in the treatment of allergic rhinitis and asthma: ARIA update (in collaboration with GA(2)LEN). Allergy. 2005;60(9):1112-1115.

18. Passalacqua G, Bousquet PJ, Carlsen KH, Kemp J, Lockey RF, et al. ARIA update: I-Systematic review of complementary and alternative medicine for rhinitis and asthma. J Allergy Clin Immunol. 2006;117 (5):1054-1062.

19. Bonini S, Bonini M, Bousquet J, Brusasco V, Canonica GW, et al. Rhinitis and asthma in athletes: An ARIA document in collaboration with GA2LEN. Allergy. 2006;61(6):681-692.

20. Bousquet J, van Cauwenberge P, Ait Khaled N, Bachert C, BaenaCagnani $\mathrm{CE}$, et al. Pharmacologic and anti-IgE treatment of allergic rhinitis ARIA update (in collaboration with GALEN). Allergy. 2006;61 (9):1086-1096

21. Passalacqua G, Durham SR. Allergic rhinitis and its impact on asthma update: Allergen immunotherapy. J Allergy Clin Immunol. 2007;119 (4):881-891.

22. Cruz AA, Popov T, Pawankar R, Annesi-Maesano I, Fokkens W, et al. Common characteristics of upper and lower airways in rhinitis and asthma: ARIA update, in collaboration with GA(2)LEN. Allergy. 2007; 62(Suppl. 84):1-41.

23. Bauchau V, Durham SR. Prevalence and rate of diagnosis of allergic rhinitis in Europe. Eur Respir J. 2004;24(5):758-764.

24. Demoly P, Allaert FA, Lecasble M, Bousquet J. Validation of the classification of ARIA (allergic rhinitis and its impact on asthma). Allergy. 2003;58(7):672-675.

25. Bachert C, van Cauwenberge P, Olbrecht J, van Schoor J. Prevalence, classification and perception of allergic and nonallergic rhinitis in Belgium. Allergy. 2006;61(6):693-698.

26. Todo-Bom A, Loureiro C, Almeida MM, Nunes C, Delgado L, Castel-Branco G, Bousquet J. Epidemiology of rhinitis in Portugal: Evaluation of the intermittent and the persistent types. Allergy. 2007; 62(9):1038-1043.

27. Van Hoecke H, Vastesaeger N, Dewulf L, De Bacquer D. van Cauwenberge $\mathrm{P}$. Is the allergic rhinitis and its impact on asthma classification useful in daily primary care practice? J Allergy Clin Immunol. 2006;118 (3):758-759.

28. Valero A, Ferrer M, Sastre J, Navarro AM, Monclús L, et al. A new criterion by which to discriminate between patients with moderate allergic rhinitis and patients with severe allergic rhinitis based on the Allergic Rhinitis and its Impact on Asthma severity items. J Allergy Clin Immunol. 2007;120(2):359-365.

29. Bousquet PJ, Combescure C, Neukirch F, Klossek JM, Méchin H, Daures JP, Bousquet J. Visual analog scales can assess the severity of rhinitis graded according to ARIA guidelines. Allergy. 2007;62(4):367-372.

30. Boot JD, de Kam ML, Mascelli MA, Miller B, van Wijk RG, et al. Nasal nitric oxide: Longitudinal reproducibility and the effects of a nasal allergen challenge in patients with allergic rhinitis. Allergy. 2007;62(4):378-384.

31. Juniper EF, Riis B, Juniper BA. Development and validation of an electronic version of the Rhinoconjunctivitis Quality of Life Question naire. Allergy. 2007;62(9):1091-1093.

32. Nizankowska-Mogilnicka E, Bochenek G, Mastalerz L, Swierczynska M, Dahlen B, et al. Aspirin provocation tests for diagnosis of aspirin sensitivity. EAACI/GA2LEN guideline. Allergy. 2007;62(10):1111-1118.

33. Bonini M, Lapucci G, Petrelli G, Todaro A, Pamich T, Rasi G, Bonini S. Predictive value of allergy and pulmonary function tests for the diagnosis of asthma in elite athletes. Allergy. 2007;62(10):1166-1170.

34. Bonini S, Rasi G, Brusasco V, Carlsen KH, Crimi E, et al. Nonspecific provocation of target organs in allergic diseases: EAACI-GA(2)LEN consensus report. Allergy. 2007;62(6):683-694.

35. Burgess JA, Walters EH, Byrnes GB, Matheson MC, Jenkins MA, et al. Childhood allergic rhinitis predicts asthma incidence and persistence to middle age: A longitudinal study. J Allergy Clin Immunol. 2007;120 (4):863-869

36. Chatkin MN, Menezes AM, Victora CG, Barros FC. High prevalence of asthma in preschool children in Southern Brazil: A population-based study. Pediatr Pulmonol. 2003;35(4):296-301.

37. Giovannini M, Agostoni C, Riva E, Salvini F, Ruscitto A, Zuccotti GV, Radaelli G. A randomized prospective double blind controlled trial on effects of long-term consumption of fermented milk containing Lactobacillus casei in pre-school children with allergic asthma and/or rhinitis. Pediatr Res. 2007;62(2):215-220. 
38. Viegi G, La Grutta S. Rhinoconjunctivitis and wheeze in preschool children: A different relationship than in adults (United or Coexistent Airways Disease)? Allergy. 2007;62(4):344-347.

39. Choi SH, Yoo Y, Yu J, Rhee CS, Min YG, Koh YY. Bronchial hyperresponsiveness in young children with allergic rhinitis and its risk factors. Allergy. 2007;62(9):1051-1056.

40. Bateman ED, Jithoo A. Asthma and allergy - a global perspective. Allergy. 2007;62(3):213-215.

41. English RG, Fairall LR, Bateman ED. Keeping allergy on the agenda: Integrated guidelines for respiratory disease in developing countries. Allergy. 2007;62(3):224-229.

42. Bousquet J, Khaltaev N, Cruz A, Denburg J, Fokkens W, et al. Allergic rhinitis and its impact on asthma (ARIA) 2008 update (in collaboration with the World Health Organization, GA(2)LEN and AllerGen). Allergy. 2008;63(suppl).

43. Schun̈emann HJ, Hill SR, Kakad M, Vist GE, Bellamy R, et al. Transparent development of the WHO rapid advice guidelines. PLoS Med. 2007;4(5):el19.

44. Brozek JL, Baena-Cagnani CE, Bonini S, Canonica GW, Rasi G, et al. Methodology for development of the Allergic Rhinitis and its Impact on Asthma guideline 2008 update. Allergy. 2008;63(1):38-46.

45. Fokkens WJ, Jogi R, Reinartz S, Sidorenko I, Sitkauskiene B, et al. Once daily fluticasone furoate nasal spray is effective in seasonal allergic rhinitis caused by grass pollen. Allergy. 2007;62(9):1078-1084.

46. Philip G, Nayak AS, Berger WE, Leynadier F, Vrijens F, Dass SB, Reiss TF. The effect of montelukast on rhinitis symptoms in patients with asthma and seasonal allergic rhinitis. Curr Med Res Opin. 2004; 20(10):1549-1558.

47. Barnes ML, Menzies D, Fardon TC, Burns P, Wilson AM, Lipworth BJ. Combined mediator blockade or topical steroid for treating the unified allergic airway. Allergy. 2007;62(1):73-80.

48. Durham SR, Riis B. Grass allergen tablet immunotherapy relieves individual seasonal eye and nasal symptoms, including nasal blockage. Allergy. 2007;62(8):954-957.

49. Durham SR, Yang WH, Pedersen MR, Johansen N, Rak S. Sublingual immunotherapy with once-daily grass allergen tablets: A randomized controlled trial in seasonal allergic rhinoconjunctivitis. J Allergy Clin Immunol. 2006;117(4):802-809.

50. Dahl R, Kapp A, Colombo G, de Monchy JG, Rak S, et al. Efficacy and safety of sublingual immunotherapy with grass allergen tablets for seasonal allergic rhinoconjunctivitis. J Allergy Clin Immunol. 2006;118 (2):434-440.

51. Didier A, Mailing HJ, Worm M, Horak F, Jäger S, et al. Optimal dose, efficacy, and safety of once-daily sublingual immunotherapy with a 5-grass pollen tablet for seasonal allergic rhinitis. J Allergy Clin Immu nol. 2007;120(6):1338-1345.

52. Canonica GW, Baena-Cagnani CE, Bousquet J, Bousquet PJ, Lockey RF, et al. Recommendations for standardization of clinical trials with Allergen Specific Immunotherapy for respiratory allergy. A statement of a World Allergy Organization (WAO) taskforce. Allergy. 2007;62(3): 317-324.

53. Clark J, Schall R. Assessment of combined symptom and medication scores for rhinoconjunctivitis immunotherapy clinical trials. Allergy. 2007;62(9):1023-1028.

54. Casale TB, Romero FA, Spierings EL. Intranasal noninhaled carbon dioxide for the symptomatic treatment of seasonal allergic rhinitis. $J$ Allergy Clin Immunol. 2008;121(1):105-109.

55. Greiner AN, Meltzer EO. Pharmacologic rationale for treating allergic and nonallergic rhinitis. J Allergy Clin Immunol. 2006;118(5):985-998.

56. Linneberg A, Jorgensen $\mathrm{T}$, Nielsen NH, Madsen F, Frolund L, Dirksen A. The prevalence of skin-test-positive allergic rhinitis in Danish adults: Two cross-sectional surveys 8 years apart. The Copenhagen Allergy Study. Allergy. 2000;55(8):767-772.

57. Terreehorst I, Oosting AJ, Tempels-Pavlica Z, de Monchy JG, Bruijn-zeel-Koomen CA, Hak E, van Wijk RG. Prevalence and severity of allergic rhinitis in house dust mite-allergic patients with bronchial asthma or atopic dermatitis. Clin Exp Allergy. 2002;32(8):1160-1165.

58. Georgy V, Fahim HI, El-Gaafary M, Walters S. Prevalence and socioeconomic associations of asthma and allergic rhinitis in northern [corrected] Africa. Eur Respir J. 2006;28(4):756-762.

59. Kuyucu S, Saraclar Y, Tuncer A, Geyik PO, Adalioglu G, et al. Epidemiologic characteristics of rhinitis in Turkish children: The Inter national
Study of Asthma and Allergies in Childhood (ISAAC) phase 2. Pediatr Allergy Immunol. 2006;17(4):269-277.

60. Antonicelli L, Micucci C, Voltolini S, Feliziani V, Senna GE, et al. Allergic rhinitis and asthma comorbidity: ARIA classification of rhinitis does not correlate with the prevalence of asthma. Clin Exp Allergy. 2007;37(6):954-960.

61. Antonicelli L, Micucci C, Voltolini S, Senna GE, Di Blasi P, et al. Relationship between ARIA classification and drug treatment in allergic rhinitis and asthma. Allergy. 2007;62(9):1064-1070.

62. Bousquet J, Gaugris S, Kocevar VS, Zhang Q, Yin DD, Polos PG, Bjermer L. Increased risk of asthma attacks and emergency visits among asthma patients with allergic rhinitis: A subgroup analysis of the improving asthma control trial. Clin Exp Allergy. 2005;35(6): 723-727.

63. Price D, Zhang Q, Kocevar VS, Yin DD, Thomas M. Effect of a concomitant diagnosis of allergic rhinitis on asthma-related health care use by adults. Clin Exp Allergy. 2005;35(3):282-287.

64. Gaugris S, Sazonov-Kocevar V, Thomas M. Burden of concomitant allergic rhinitis in adults with asthma. J Asthma. 2006;43(1):1-7.

65. Solé D, Camelo-Nunes IC, Wandalsen GF, Melo KC, Naspitz CK. Is rhinitis alone or associated with atopic eczema a risk factor for severe asthma in children? Pediatr Allergy Immunol. 2005;16(2):121-125.

66. Kanani AS, Broder I, Greene JM, Tarlo SM. Correlation between nasal symptoms and asthma severity in patients with atopic and nonatopic asthma. Ann Allergy Asthma Immunol. 2005;94(3):341-347.

67. Leynaert B, Bousquet J, Henry C, Liard R, Neukirch F. Is bronchial hyperresponsiveness more frequent in women than in men? A population-based study. Am J Respir Crit Care Med. 1997;156(5):1413-1420.

68. Sotomayor H, Badier M, Vervloet D, Orehek J. Seasonal increase of carbachol airway responsiveness in patients allergic to grass pollen. Reversal by corticosteroids. Am Rev Respir Dis. 1984;130(1):56-58.

69. Lombardero M, Garcia-Sellés FJ, Polo F, Jimeno L, Chamorro MJ, et al. Prevalence of sensitization to Artemisia allergens Art v 1, Art v 3 and Art v $60 \mathrm{kDa}$. Cross-reactivity among Art v 3 and other relevant lipid-transfer protein allergens. Clin Exp Allergy. 2004;34(9):1415-1421.

70. Bonay M, Neukirch C, Grandsaigne M, Lecon-Malas V, Ravaud P, Dehoux M, Aubier M. Changes in airway inflammation following nasal allergic challenge in patients with seasonal rhinitis. Allergy. 2006;61 (1):111-118.

71. Bousquet J, Jacquot W, Vignola AM, Bachert C, Van Cauwenberge P, Jacquot W. Allergic rhinitis: A disease remodeling the upper airways? J Allergy Clin Immunol. 2004;113(1):43-49.

72. Taramarcaz P, Gibson PG. The effectiveness of intranasal corticoste roids in combined allergic rhinitis and asthma syndrome. Clin Exp Allergy. 2004;34(12):1883-1889.

73. Bousquet J, Boushey HA, Busse WW, Canonica GW, Durham SR, et al. Characteristics of patients with seasonal allergic rhinitis and concomitant asthma. Clin Exp Allergy. 2004;34(6):897-903.

74. Stelmach R, do Patrocinio T Nunes M, Ribeiro M, Cukier A. Effect of treating allergic rhinitis with corticosteroids in patients with mild-tomoderate persistent asthma. Chest. 2005;128(5):3140-3147.

75. Camargos P, Ibiapina C, Lasmar L, Cruz AA. Obtaining concomitant control of allergic rhinitis and asthma with a nasally inhaled corticosteroid. Allergy. 2007;62(3):310-316.

76. Jacobsen L, Niggemann B, Dreborg S, Ferdousi HA, Halken S, et al. Specific immunotherapy has long-term preventive effect of seasonal and perennial asthma: 10-year follow-up on the PAT study. Allergy. 2007;62 (8):943-948.

77. Civelek E, Soyer OU, Gemicioglu B, Sekerel BE. Turkish physicians' perception of allergic rhinitis and its impact on asthma. Allergy. 2006;61 (12):1454-1458.

78. Demoly P, Concas V, Urbinelli R, Allaert F. Evaluation de l'influence des recommandations OMS-ARIA sur la prise en charge de la rhinite allergique en pratique de ville en France. Enguete ERNANI. Rev fr Allergol Immunol Clin. 2006;46:626-632.

79. Adams RJ, Fuhlbrigge AL, Finkelstein JA, Weiss ST. Intransal steroids and the risk of emergency department visits for asthma. J Allergy Clin Immunol. 2002;109:636-642.

80. Björkstén B, Clayton T, Ellwood P, Stewart A, Strachan D; Phase III Study Group II. Worldwide time trends for symptoms of rhinitis and conjunctivitis: Phase III of the International Study of Asthma and Allergies in Childhood. Pediatr Allergy Immunol. 2008;19(2):110-124. 
81. Pearce N, Ait-Khaled N, Beasley R, Mallol J, Keil U, Mitchell E, Robertson C; ISAAC Phase III Study Group. Worldwide trends in the prevalence of asthma symptoms: Phase III of the International Study of Asthma and Allergies in Childhood (ISAAC). Thorax. 2007;62(9): 758-766.

82. Nishima S. A study on the prevalence of bronchial asthma in school children in western districts of Japan-comparison between the studies in 1982 and in 1992 with the same methods and same districts. Arerugi. 1993;42(3 Pt 1):192-204.

83. Hsieh KH, Shen JJ. Prevalence of childhood asthma in Taipei, Taiwan and other Asian Pacific countries. J Asthma. 1988;25:73-82.

84. Chiang LC, Chen YH, Hsueh KC, Huang JL. Prevalence and severity of symptoms of asthma, allergic rhinitis, and eczema in 10- to 15-year-old school children in central Taiwan. Asian Pac J Allergy Immunol. 2007;25(1):1-5.

85. Droma Y, Kunii O, Yangzom Y, Shan M, Pingzo L, Song P. Prevalence and severity of asthma and allergies in schoolchildren in Lhasa, Tibet. Clin Exp Allergy. 2007;37(9):1326-1333.

86. Zaman K, Takeuchi H, Yunus Md, El Arifeen S, Chowdhury HR, et al. Asthma in rural Bangladeshi children. Indian J Pediatr. 2007;74 (6):539-543.

87. Aggarwal AN, Chaudhry K, Chhabra SK, D'Souza GA, Gupta D, et al. Prevalence and risk factors for bronchial asthma in Indian adults: A multicentre study. Indian J Chest Dis Allied Sci. 2006;48(1):13-22.

88. Nga NN, Chai SK, Bihn TT, Redding G, Takaro T, Checkoway H, Son PH, Van DK, Keifer M, Trung le V, Barnhart S. ISAAC-based asthma and atopic symptoms among Ha Noi school children. Pediatr Allergy Immunol. 2003;14(4):272-279.
89. Australian Centre for Asthma Monitoring. Available at: www. asthmamonitoring.org. Accessed April 9, 2012.

90. Zhang L, Han D, Huang D, Wu Y, Dong Z, et al. Prevalence of selfreported allergic rhinitis in eleven major cities in China. Int Arch Allergy Immunol. 2009;149(1):47-57.

91. Kim YM, Lee CH, Kim JH, Lee JM, Rhee CS, et al. Prevalence of allergic rhinitis on the basis of ARIA classification. Korean J Otolaryngol - Head Neck Surg. 2006;49(6):623-628.

92. Kim TB, Kim YK, Chang YS, Kim SH, Hong SC, et al. Association between sensitization to outdoor spider mites and clinical manifestations of asthma and rhinitis in the general population of adults. $J$ Korean Med Sci. 2006;21:247-252.

93. Kim CW, Lee CW, Hur GY, Ye YM, Park HS; CARINA Study Group. Evaluation and control of allergic rhinitis in adult patients with asthma (CARINA) in Korea. Korean J Asthma Allergy Clin Immunol. 2007;27 (4):248-256.

94. Daengsuwan T, Lee BW, Visitsuntorn N, Charoenratanakul S, Ruangrak S, Jirapongsananuruk O, Vichyanond P. Allergen sensitization to aeroal- lergens including Blomia tropicalis among adult and childhood asthmatics in Thailand. Asian Pac J Allergy Immunol. 2003;21 (4):199-204.

95. Zainudin BM, Lai CK, Soriano JB, Jia-Horng W, De Guia TS. Asthma Insights and Reality in Asia-Pacific (AIRIAP) Steering Committee. Asthma control in adults in Asia-Pacific. Respirology. 2005;10(5):579-586.

96. Pawankar R, Baena-Cagnani C, Bousquet J, Canonica GW, Cruz AA, Kaliner MA, Lanier BQ. State of World Allergy Report 2008: Allergy and Chronic Respiratory Diseases. WAO J. 2008;Suppl:S4-S17. 